\title{
Detection of food-borne bacteria in ready to eat betel leaf sold at local markets in Mymensingh
}

\author{
Md. Mazedul Haque, Md. Atiqur Rahman Sarker, Rafia Afroze Rifa, Md. Ariful Islam and Mst. Minara Khatun \\ Department of Microbiology and Hygiene, Faculty of Veterinary Science, Bangladesh Agricultural University, \\ Mymensingh 2202, Bangladesh. \\ Corresponding author: Mst. Minara Khatun, e-mail: minaramicro2003@yahoo.com \\ Co-authors: MMH: mazedul87@gmail.com, MARS: tushar33vet@gmail.com, \\ RAR: rafiaafroze05@gmail.com, MAI: islamma@bau.edu.bd \\ Received: 24-04-2017, Accepted: 08-08-2017, Published online: 11-09-2017
}

doi: 10.14202/vetworld.2017.1040-1045 How to cite this article: Haque MM, Sarker MAR, Rifa RA, Islam MA, Khatun MM (2017) Detection of food-borne bacteria in ready to eat betel leaf sold at local markets in Mymensingh, Veterinary World, 10(9): 1040-1045.

\begin{abstract}
Aim: The present study was undertaken to determine bacterial load as well as characterize bacterial flora of ready to eat (RTE) betel leaf sold at local markets in Mymensingh city.
\end{abstract}

Materials and Methods: A total of 25 RTE betel leaf samples were collected from five local markets such as Kamal-Ranjit (KR) market, Shesh more, Kewatkhali, Jobber more, and Ganginar par.

Results: Total viable count of bacteria in betel leaf $\left(\log _{10}\right.$ mean colony forming unit \pm standard deviation $\left./ \mathrm{ml}\right)$ was $7.58 \pm 0.04$ for KR market, $7.72 \pm 0.06$ for Shesh more, $7.62 \pm 0.04$ for Kewatkhali, $7.40 \pm 0.03$ for Jobber more, and $7.60 \pm 0.06$ for Ganginar par. A total of 98 bacterial isolates belong to five genera (Escherichia coli, Salmonella spp., Vibrio spp., Bacillus spp., and Staphylococcus spp.) were identified. The prevalence of E. coli was $17.34 \%$, Salmonella spp. was $25.51 \%$, Vibrio spp. was $19.39 \%$, Bacillus spp. was $18.37 \%$, and Staphylococcus spp. was $19.39 \%$. Antibiotic sensitivity test showed that all isolates were sensitive to two antibiotics such as ciprofloxacin and gentamicin. Four isolates (E. coli, Salmonella spp., Vibrio spp., and Staphylococcus spp.) were resistant to two antibiotics (ampicillin and cephalexin). Antibiogram profile of bacterial isolates of betel leaf suggests that they were multidrug resistance.

Conclusion: Data of this study indicate that betel leaf sold at local market harbors multidrug resistance food-borne bacteria which might cause public health hazards if these antibiotic resistant transfer to human through food chain.

Keywords: betel leaf, food-borne bacteria, Mymensingh city, public health importance.

\section{Introduction}

Betel leaf commonly known as paan belongs to the family Piperaceae [1], and the scientific name is Piper betle [2]. Paan is extensively grown in Bangladesh, India, Sri Lanka, Malaysia, Indonesia, Philippines, and East Africa [3]. In Bangladesh, huge numbers of peoples consume paan daily which is more common in people aged 35-60 years. The significance of the leaves has been explained in relation to every sphere of human life including social, cultural, religious, medicinal, and even daily life such as marriage, puja, and Sraddha ceremony.

Bangladesh earns US\$ 8 million per year by exporting betel leaf to European country which contributes a great to our national economy [4]. However, the European Union (EU) could detect the contaminated Salmonella in Bangladeshi betel leaves which was harmful for health and caused diarrhea and vomiting and other related serious illness to the people who consumed it, and ultimately, the EU stopped the importation

Copyright: Haque, et al. Open Access. This article is distributed under the terms of the Creative Commons Attribution 4.0 International License (http://creativecommons.org/licenses/by/4.0/), which permits unrestricted use, distribution, and reproduction in any medium, provided you give appropriate credit to the original author(s) and the source, provide a link to the Creative Commons license, and indicate if changes were made. The Creative Commons Public Domain Dedication waiver (http://creativecommons.org/ publicdomain/zero/1.0/) applies to the data made available in this article, unless otherwise stated. of betel leaf from Bangladesh [5]. Export of paan leaves from Bangladesh is under a great threat. Our previous studies showed the efficacy of vinegar, sorbitol, and sodium benzoate in mitigation of Salmonella contamination in betel leaf [6]. Research work on the isolation, identification, and characterization of bacteria from the betel leaf has not been conducted in Bangladesh.

The aim of this study was to determine bacterial load as well as to isolate and identify bacteria from betel leaves collected from different local markets of Mymensingh.

\section{Materials and Methods \\ Ethical approval}

The experiment was approved by Institutional Ethical Committee, Faculty of Veterinary Science, Bangladesh Agricultural University, Mymensingh 2202, Bangladesh.

\section{Collection and transportation of betel leaf (paan) samples}

A total of 25 betel leaf samples were collected from five different local markets such as Kamal-Ranjit (KR) market, Shesh more, Kewatkhali, Jobber more, and Ganginar par in Mymensingh (Table-1). Individual sample was placed in the sterile polythene bag. The samples were transported carefully to the bacteriology laboratory using an icebox for bacteriological analysis. 
Table-1: Summary of betel leaf samples collected from local markets.

\begin{tabular}{lcc}
\hline Name of markets & $\begin{array}{c}\text { Number of betel leaf } \\
\text { collected from each market }\end{array}$ & Total \\
\hline KR & 5 & 25 \\
Shesh more & 5 & \\
Kewatkhali & 5 & \\
Jobber more & 5 & \\
Ganginar par & 5 & \\
\hline
\end{tabular}

$\mathrm{KR}=$ Kamal-Ranjit

\section{Washing of betel leaf samples}

The betel leaf samples in polythene bag were washed with sterile phosphate-buffered saline (PBS). One betel leaf was washed with $20 \mathrm{ml}$ of sterile PBS. A 10-fold serial dilution of the washed samples was prepared in nutrient broth. Five betel leaf samples from each market were washed and analyzed for isolation of bacteria.

\section{Determination of total viable count (TVC)}

A total of $0.5 \mathrm{ml} \mathrm{10-fold} \mathrm{diluted} \mathrm{sample}\left(10^{-1}\right.$ to $10^{-7}$ ) was transferred and spreaded onto plate count agar and incubated at $37^{\circ} \mathrm{C}$ for $24-48 \mathrm{~h}$. The number of colonies (30-300) in a particular dilution was multiplied by the dilution factor to calculate TVC which was expressed as mean $\log _{10} \pm$ standard deviation colony-forming unit (CFU)/ml.

\section{Isolation and identification of bacteria}

Isolation and identification of bacteria were performed according to the method described by Carter [7]. Washing of betel leaf was enriched in nutrient broth at $37^{\circ} \mathrm{C}$ for overnight. The overnight cultures were streaked on eosin methylene blue (EMB) agar for Escherichia coli, SalmonellaShigella agar or xylose-lysine deoxycholate (XLD) agar for Salmonella spp., thiosulfate-citrate-bile salts-sucrose (TCBS) agar for Vibrio spp., blood agar for Bacillus spp., and mannitol salt (MS) agar for Staphylococcus spp. and incubated at $37^{\circ} \mathrm{C}$ for $24 \mathrm{~h}$. Single colony was further subcultured until pure culture was obtained. Identification of bacteria was performed on the basis of colony morphology; Gram's staining reaction, motility test, and biochemical tests.

\section{Molecular detection of $E$. coli by polymerase chain reaction (PCR)}

DNA extraction

A pure bacterial colony of $E$. coli was mixed with $100 \mu \mathrm{l}$ of distilled water which was boiled for $10 \mathrm{~min}$ then immediately kept on ice for cold shock. Finally, centrifugation was done at $10,000 \mathrm{rpm}$ for $10 \mathrm{~min}$. The supernatant was collected and used as DNA template for PCR.

\section{Primers used for PCR}

A genus-specific PCR was performed to amplify $16 \mathrm{~S}$ rRNA of $E$. coli using previously published primers [8]. The list of primers is shown in Table-2.

\section{Antibiotic sensitivity test}

Five isolates randomly selected from five genera were tested for antimicrobial drug susceptibility against five commonly used antibiotics such as ampicillin, chloramphenicol, ciprofloxacin, gentamicin, and cephalexin by disc diffusion or KirbyBauer method [9]. Antimicrobial testing results were recorded as susceptible, intermediate, and resistant according to zone diameter interpretative standards provided by the Clinical and Laboratory Standards Institute [10].

\section{Statistical analysis}

The results of TVC of bacteria of betel leaf sold at local markets were analyzed for statistical significance using Duncan's multiple range test (SPSS, 11.5). A $\mathrm{p}<0.05$ was considered to be statistically significant.

\section{Results}

\section{TVC of betel leaf}

The TVC of betel leaf samples collected from different markets is presented in Figure-1. A number of bacterial isolates recovered from betel leaf sold at different markets are shown in Figure-2.

\section{Isolation of bacteria from betel leaf}

A total of 98 bacterial isolates belonged to five genera of bacteria such as E. coli, Salmonella spp., Vibrio spp., Bacillus spp., and Staphylococcus spp. were isolated from 25 betel leaf samples (Table-3).

\section{Results of biochemical test}

Results of sugar fermentation tests using five basic sugars such as dextrose, maltose, lactose, sucrose, and mannitol and other biochemical tests such as methyl red (MR) and Voges-Proskauer (VP) are listed in Table-4.

In sugar fermentation test, E. coli fermented all five basic sugars such as dextrose, maltose, lactose, sucrose, and mannitol and produced acid and gas. Salmonella spp. fermented dextrose, maltose, and mannitol and produced only acid, whereas lactose and sucrose were negative. Vibrio spp. fermented dextrose, maltose, sucrose, and mannitol and produced acid, whereas lactose was negative. Bacillus spp. fermented dextrose, sucrose, and mannitol and produced acid and gas. Bacillus spp. also fermented maltose and lactose and produced only acid. Staphylococcus spp. fermented all sugars and produced acid.

All isolates of $E$. coli were MR and Indole positive but VP and catalase negative; Salmonella was MR positive but VP, indole, and catalase negative; Vibrio was MR, indole, and catalase positive but VP negative; and Bacillus was MR and indole positive but VP and catalase negative.

Prevalence of E. coli, Salmonella spp., Vibrio spp., Bacillus spp., and Staphylococcus spp. recovered from betel leaf

The prevalence of $E$. coli was $17.34 \%$ (17 of 98), Salmonella spp. was $25.51 \%$ (25 of 98), Vibrio 
spp. was $19.39 \%$ (19 of 98), Bacillus spp. was $18.37 \%$ (18 of 98), and Staphylococcus spp. was 19.39 (19 of 98). The overall prevalence of E. coli, Salmonella spp., Vibrio spp., Bacillus spp., and Staphylococcus spp. in betel leaf samples is presented in Figure-3.

\section{Molecular detection of $E$. coli}

DNA extracted from five $E$. coli isolates was used in the PCR assay. PCR primers targeting 16S

Table-2: PCR primers with sequence.

\begin{tabular}{llc}
\hline Primer & Sequence & $\begin{array}{l}\text { Size } \\
\text { (bp) }\end{array}$ \\
\hline E. coli 16S (F) & 5'-AATTGAAGAGTTTGATCATG-3' $^{\prime}$ & 704 \\
E. coli 16S (R) & 5'-CTCTACGCATTTCACCGCTAC-3' & \\
\hline
\end{tabular}

$\mathrm{F}=$ Forward, $\mathrm{R}=$ Reverse, $\mathrm{bp}=$ Base pair, $\mathrm{PCR}=$ Polymerase chain reaction, E. coli=Escherichia coli

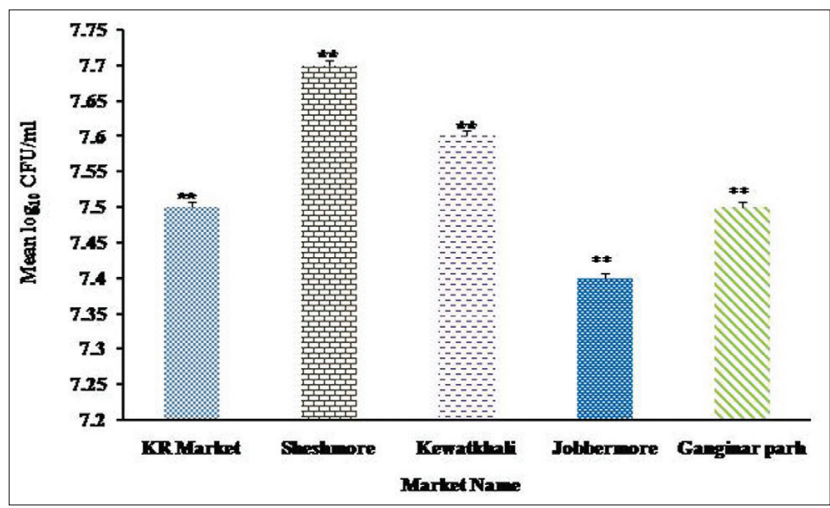

Figure-1: Total viable counts of bacteria recovered from betel leaf sold at Kamal-Ranjit markets, Shesh more, Kewatkhali, Jobber more, and Ganginar par markets. The result is expressed as mean $\log _{10}$ colony-forming unit of 5 samples \pm standard deviation $/ \mathrm{ml}$. The bacterial load recorded in betel leaf sold in all local markets was found to be statistically significant $(* * p<0.01)$.

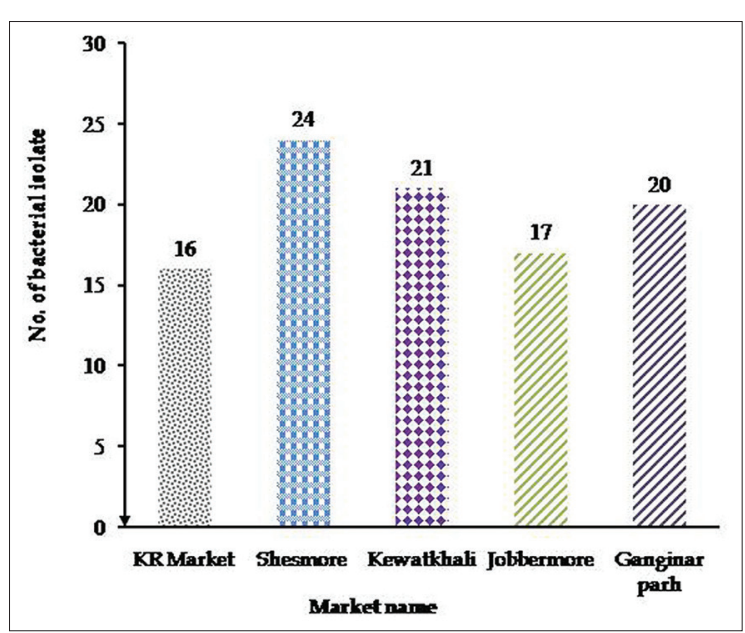

Figure-2: Number of bacterial isolates recovered from betel leaf sold at Kamal-Ranjit (KR) market, Shesh more, Kewatkhali, Jobber more, and Ganginar par. The highest number of bacteria was recovered from Shesh more (24 isolates from 5 samples), followed by Kewatkhali ( 21 isolates from 5 samples), Jobber more (17 isolates from 5 samples), Ganginar par (20 isolates from 5 samples), and KR market (16 isolates from 5 samples).
rRNA of E. coli amplified 704 bp fragments of DNA confirming the identity of E. coli (Figure-4).

\section{Results of antibiotics sensitivity tests}

One isolate randomly selected from each genus (E. coli, Salmonella sp., Vibrio sp., Bacillus sp., and Staphylococcus sp.) was subjected to antibiotic sensitivity test against five commonly used antibiotics such as ciprofloxacin, ampicillin, cephalexin, gentamicin, and chloramphenicol. The zone of inhibition of five antibiotics against tested bacteria is shown in Figure-5.

Summary of antibiogram profile of E. coli, Salmonella sp., Vibrio sp., Bacillus sp., and Staphylococcus sp. against antibiotics is presented in Figure-6.

\section{Discussion}

Consumption of ready-to-eat (RTE) food items including betel leaf with food-borne bacteria is an important obstacle in international trade as well as public health issue worldwide. The present research

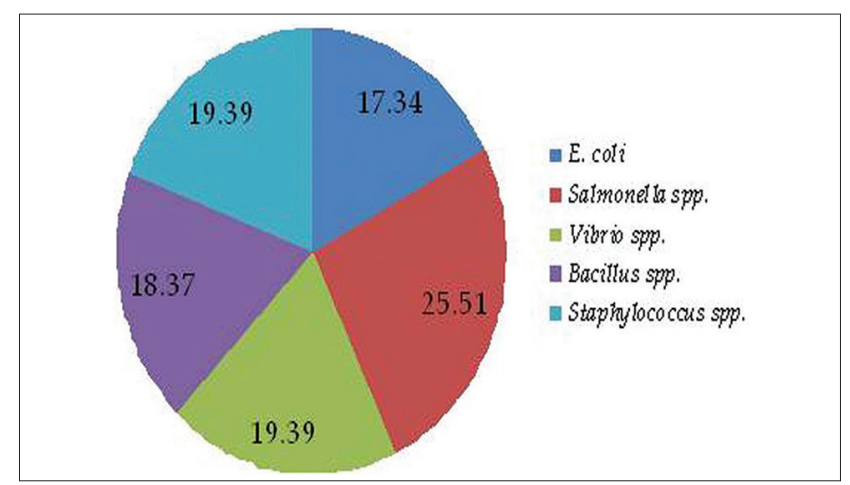

Figure-3: The prevalence of Escherichia coli, Salmonella spp., Vibrio spp., Bacillus spp., and Staphylococcus spp.

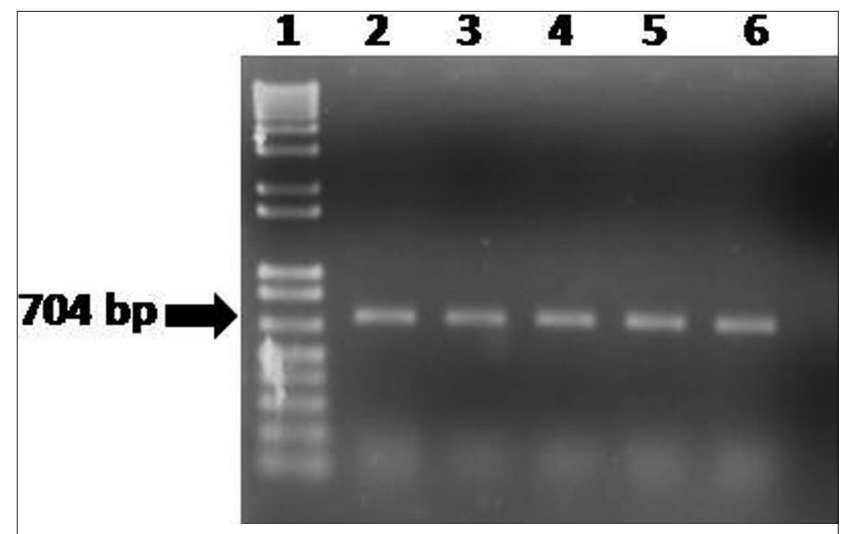

Figure-4: Polymerase chain reaction assay to amplify $16 \mathrm{~S}$ rRNA of Escherichia coli isolates recovered from betel leaf sold at five local markets in Mymensingh. Lanes: 1 - 100$12 \mathrm{~kb}$ size DNA marker (Trackit, Invitrogen, USA); 2 - DNA of $E$. coli isolate of betel leaf sold at Kamal-Ranjit market; 3 - DNA of $E$. coli isolates of betel leaf sold at Shesh more market; 4 - DNA of $E$. coli isolates of betel leaf sold at Kewatkhali market; 5 - DNA of $E$. coli isolates of betel leaf sold at Jobber more; 6 - DNA of $E$. coli isolates of betel leaf sold at Ganginar par market; and 7 - Negative control without DNA. 
Table-3: Summary of isolation of bacteria from betel leaf sold at local markets in Mymensingh.

\begin{tabular}{lccccc}
\hline Name of local markets & \multicolumn{4}{c}{ Bacterial genera } \\
\cline { 2 - 6 } & $\begin{array}{c}\text { E. coli } \\
(\mathbf{n})\end{array}$ & $\begin{array}{c}\text { Salmonella } \\
\text { spp. (n) }\end{array}$ & $\begin{array}{c}\text { Vibrio } \\
\text { spp. (n) }\end{array}$ & $\begin{array}{c}\text { Bacillus } \\
\text { spp. (n) }\end{array}$ & $\begin{array}{c}\text { Staphylococcus } \\
\text { spp. (n) }\end{array}$ \\
\hline KR market & 4 & 5 & 4 & 3 & ND \\
Shesh more & 5 & 5 & 4 & 5 & 5 \\
Kewatkhali & 4 & 5 & 3 & 4 & 5 \\
Jobber more & ND & 5 & 4 & 3 & 5 \\
Ganginar par & 4 & 5 & 4 & 3 & 4 \\
Total & 17 & 25 & 19 & 18 & 19 \\
\hline
\end{tabular}

$\mathrm{KR}=$ Kamal-Ranjit, ND=Not detected, E. coli=Escherichia coli

Table-4: Biochemical characteristics of E. coli, Salmonella spp., Vibrio spp., Bacillus spp., and Staphylococcus spp.

\begin{tabular}{|c|c|c|c|c|c|c|c|c|c|}
\hline \multicolumn{5}{|c|}{$\begin{array}{l}\text { Sugar fermentation } \\
\text { reaction profiles }\end{array}$} & \multirow[t]{2}{*}{ MR test } & \multirow[t]{2}{*}{ VP test } & \multirow[t]{2}{*}{ Indole production test } & \multirow[t]{2}{*}{ Catalase test } & \multirow[t]{2}{*}{ Interpretation } \\
\hline DX & ML & $\mathbf{L}$ & $\mathbf{S}$ & MN & & & & & \\
\hline AG & AG & AG & AG & AG & + & - & + & - & E.coli \\
\hline A & A & - & - & A & + & - & - & - & Salmonella spp. \\
\hline$A$ & $A$ & - & $A$ & $A$ & + & - & + & + & Vibrio spp. \\
\hline AG & $A$ & $A$ & $A G$ & $A G$ & + & - & + & - & Bacillus spp. \\
\hline$A$ & $A$ & $A$ & $A$ & A & + & + & - & + & Staphylococcus spp. \\
\hline
\end{tabular}

$\mathrm{DX}=$ Dextrose, $\mathrm{ML}=$ Maltose, $\mathrm{L}=$ Lactose, $\mathrm{S}=$ Sucrose, $\mathrm{MN}=$ Mannitol, $\mathrm{A}=\mathrm{Acid}, \mathrm{AG}=$ Acid and gas, $+=$ Positive, $-=$ Negative, $\mathrm{MR}=$ Methyl red, $\mathrm{VP}=$ Voges-Proskauer, E.coli=Escherichia coli

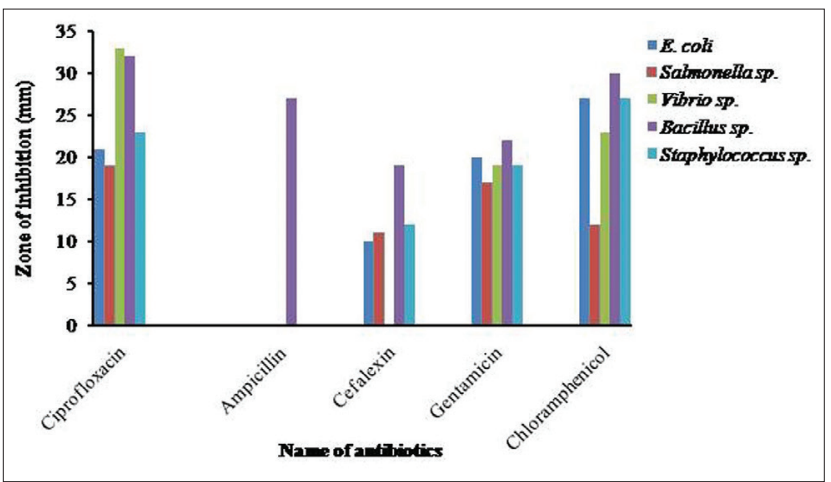

Figure-5: Zone of inhibition of ciprofloxacin, ampicillin, cephalexin, gentamicin, and chloramphenicol against Escherichia coli, Salmonella sp., Vibrio sp., Bacillus sp., and Staphylococcus sp.

work was undertaken to measure bacterial loads and identification of bacteria in betel leaf sold at local markets in Mymensingh city.

In this study, TVC of bacteria in betel leaf sample sold at different local markets ranged from log $7.403 \mathrm{CFU} / \mathrm{ml}$ to $\log 7.718 \mathrm{CFU} / \mathrm{ml}$ which was higher than the permissible limit $(10-100 \mathrm{CFU} / \mathrm{ml})$. Higher TVC recorded in this study might be resulted from lack of hygienic measures during cultivation, harvesting, transportation, and selling of betel leaf. A study conducted in restaurant salad vegetables in Chittagong city recorded 5.20-6.87 log CFU/g TVC [11]. In Nigeria, TVC of RTE salad vegetables was ranged from 6.20 to $8.47 \log \mathrm{CFU} / \mathrm{g}$ [12].

In this study, the highest TVC of betel leaf was found at Shesh more $(\log 7.718 \mathrm{CFU} / \mathrm{ml})$ and the lowest TVC was recorded at Jobber more (log $7.403 \mathrm{CFU} / \mathrm{ml}$ ). The variation of TVC in betel leaf sold at local markets is statistically significant $(p<0.05)$.
This higher TVC of betel leaf might be due to unsanitary environment, use of polluted water to wash betel leaf, and unclean utensil used to storage betel leaf.

In this study, five different genera of bacteria were isolated from betel leaf. The prevalence of Salmonella spp. was the highest $(25.52 \%)$, and E. coli prevalence was the lowest (17.34\%). Fakruddin et al. (2017) found that $77 \%$ betel leaf sample collected from different markets of Dhaka city was found to be contaminated with Salmonella spp. [13]. A study conducted in India isolated from RTE betel leaves [14]. Mishra and Mishra [15] isolated Xanthomonas campestris pv. Betticola bacteria from diseased betel leaves. In a separate study conducted by Sharmin [16], isolated E. coli, Salmonella spp., Vibrio spp., and Bacillus spp. from RTE salad vegetables sold at different local markets in Mymensingh city. E. coli, Salmonella spp., Vibrio spp., Bacillus spp., and Staphylococcus spp. are some of food-borne pathogen associated with food-borne infection and intoxication. Foods can be contaminated at many points in the food preparation, storage, and handling process. In this study, betel leaves might be contaminated with bacteria due to the use of dirty water for washing, handling of betel leaves with unclean hands, and use of unclean utensil or cutting board when preparing RTE betel leaves.

In this study, various selective media were used for isolation of $E$. coli from samples. Colony characteristics of E. coli observed in EMB were similar to the findings of Sharada et al. [17]. Morphologically, E. coli was Gram-negative short rod arranged in single or paired and motile. Thomas et al. [18] found similar cultural, staining, and motility characteristics of $E$. coli. The identified bacteria were reconfirmed by sugar fermentation and other biochemical tests 


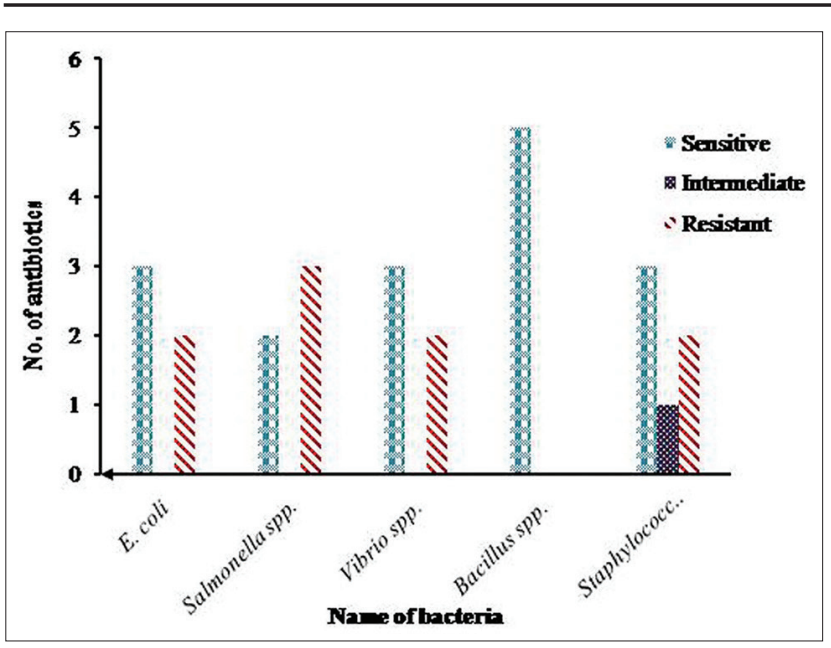

Figure-6: Summary of antibiogram profile of Escherichia coli, Salmonella spp., Vibrio spp., Bacillus spp., and Staphylococcus spp. against five antibiotics. E. coli was sensitive to 3 and resistant to 2 antibiotics, Salmonella spp. was sensitive to 2 and resistant to 3 antibiotics, Vibrio spp. was sensitive to 3 and resistant to 2 antibiotics, Bacillus spp. was totally sensitive to 5 antibiotics, and Staphylococcus spp. was sensitive to 3 and intermediately sensitive to 1 antibiotic but was resistant to 2 antibiotics.

which were found similar with the findings of Thomas et al. [18].

In this study, the colony characteristics of Vibrio spp. on TCBS agar plate were similar to the findings of Khan et al. [19]. In Gram's staining, bacteria exhibited curved rod-shaped appearance which was also observed by other researchers [20,21]. In this study, Vibrio spp. fermented dextrose, maltose, mannitol, and sucrose with the production of acid but gave a negative result to VP test [21].

In this study, the colonies of Salmonella spp. on XLD agar plate were opaque, translucent with black centers which were similar to the findings of Cheesbrough [22]. In Gram's staining, Salmonella spp. exhibited short rods, Gram-negative, single, or paired in arrangement. Similar findings were also reported by Buxton and Fraser [23]. Sugar fermentation tests profile of Salmonella spp. in the present study showed similarities with the findings of Cowan [24]. Morphology and staining characteristics of Bacillus spp. recorded in this study are in agreement with the findings of Merchant and Packer [25]. Bacillus spp. fermented five basic sugars with the production of acid [26].

Colony characteristics of Staphylococcus spp. observed in MS agar were similar to the findings of Chatterjee et al. [27] who recorded golden, yellow, and white color colonies. Staphylococcus spp. isolates in this study fermented glucose, maltose, lactose, sucrose, and mannitol fermentation with only acid production. These findings are in close agreement with the findings of Chatterjee et al. [27].

In this study, antibiotic sensitivity assay showed that all bacterial isolates were resistant to ampicillin. Four isolates such as E. coli, Salmonella spp., Vibrio spp., Bacillus spp., and Staphylococcus spp. exhibited multidrug-resistant profile. Salmonella spp., in this study, showed resistant against three antibiotics. Singh et al. [14] isolated multidrug-resistant Salmonella from RTE betel leaves in North Indian cities. In this study, Salmonella spp. was found sensitive to ciprofloxacin and resistant to chloramphenicol. Salmonella spp. isolated from betel leaves was found sensitive to both ciprofloxacin and chloramphenicol [14]. Indiscriminate use of antibiotic is responsible for the emergence of multidrug-resistant E. coli [28].

\section{Conclusion}

Data of this study suggest that betel leaves sold at local markets of Mymensingh city harbor multidrug-resistant bacteria which underscore the need of implementation of hygienic practices during production, harvesting, transportation, storage, selling, and preparation of betel leaves to safeguard public health.

\section{Authors' Contributions}

MMK and MAI designed the study. MMH and MARS collected and processed the samples for isolation and identification of bacteria. MMH, MARS, and RAR were done PCR and electrophoresis. MMH and MMK interpreted the results and analyzed the data. MMH, MAI, and MMK prepared the manuscript. All authors read and approved the final manuscript.

\section{Acknowledgments}

The authors are thankful to University Grants Commissions (UGC), for providing financial support (Project No: 2014/77/UGC) to carry out the work.

\section{Competing Interests}

The authors declare that they have no competing interests.

\section{References}

1. Shameem, P.M.D., Thirumal, M., Srilekha, A., Ushajain, D., Kumar, V.V., Kumar, S.N., Rishi, I.A., Nayak, C.N. and Chandy, V. (2013) A preliminary antimicrobial screening on leaves of Piper betle Linn. Contemp. Invest. Obs. Pharm., 2: 22-26.

2. Chakraborty, D. and Shah, B. (2011) Antimicrobial, anti-oxidative and anti-hemolytic activity of Piper betle leaf extracts. Int. J. Pharm. Pharm. Sci., 3: 192-199.

3. Parmer, V.S., Jain, S.C. andBisht, K.S.(1997)Phytochemistry of genus Piper. Phytochemistry, 46: 597-673.

4. Karim, R. (2014) Infected betel leaves threaten tk $15 \mathrm{~b}$ export of fresh fruits, vegetable to EU. http:/www.thefinancialexpress-bd.com/2014/05/27/36134/print. Accessed on 06-06-2014.

5. Chowdhury, K.R. and Kallol, A.S. (2013) EC Warns Bangladesh of Illegal Betel Leaves Export. Dhaka Tribune. Available from: http://www.dhakatribune.com/business/ commerce/2014/02/05/ec-warns-bangladesh-of-illegal-betel-leaves-export/ Accessed on 06-02-2017.

6. Husna, A.A., Islam, M.A., Rahman, M.T. and Khatun, M.M. (2015) Efficacy of vinegar, sorbitol and sodium benzoate in mitigation of Salmonella contamination in betel leaf. J. $A d v$. Vet. Anim. Res., 2: 190-194.

7. Carter, G.R. (1986) Studies on Pasteurella multocida. A hemaglutination test for the identification of serological 
types. J. Vet. Res., 16: 481-484.

8. Guan, S., Xu, R., Chen, S., Odumeru, J. and Gyles, C. (2002) Development of a procedure for discriminating among Escherichia coli isolates from animal and human sources. Appl. Environ. Microbiol., 68: 2690-2698.

9. Bauer, A.W., Kirby, W.M.M., Shrris, J.C. and Truck, M. (1966) Antibiotic susceptibility testing by a standardized single disc method. Am. J. Clin. Pathol., 45: 493-496.

10. CLSI. (2012) Performance Standards for Antimicrobial Susceptibility Testing: Twenty Second Informational Supplement M100-S22. Vol. 32. Clinical and Laboratory Standards Institute (CLSI), Wayne, PA. p10-78.

11. Nawas, T., Mazumdar, R.M., Das, S., Nipa, N.N., Islam, S., Bhuiyan, H.R. and Ahmad, I. (2012) Microbiological quality and anti-biogram of E. coli, Salmonella and Vibrio of salad and water from restaurants of Chittagong. J. Environ. Sci. Nat. Resour., 5: 159-166.

12. Mercy, A.I., Peters, O. and Kolo, I. (2011) Bacterial contaminants of salad vegetables in Abuja Municipal Area Council, Nigeria. Malays. J. Microbiol., 7: 111-114.

13. Fakruddin, M., Sultana, R., Hossain, M.N., Rahaman, M.M., Kamrul, M.I. and Ahmed, M.M. (2017) Occurrence of ingression of Salmonella spp. In betel leaf (Piper betle L.). Int. J. Food. Contam., 4: 1-10.

14. Singh, B.R., Singh, M., Singh, P., Babu, N., Chandra, M. and Agarwal, R.K. (2006) Prevalence of multidrug- resistant Salmonella on ready-to-eat betel leaves (Paan) and in water used for soaking betel leaves in North Indian cities. J. Food Prot., 69: 288-292.

15. Mishra, V. and Mishra, A. (2005) A study of betel leaf microflora. Asian J. Exp. Sci., 19: 59-62.

16. Sharmin, S. (2013) Characterization of bacteria from salad vegetables of local markets and its public health implications. M.S. Thesis. Department of Microbiology and Hygiene, Faculty of Veterinary Science, BAU, Mymensingh.

17. Sharada, R., Krishnappa, G., Raghavan, R., Sreevinas, G. and Upandra, H.A. (1999) Isolation and serotyping of Escherichia coli from different pathological conditions in poultry. Indian J. Poult. Sci., 34: 366-369.

18. Thomas, A.R., Bruce, A.D., Stacy, A., Genagon, N.M., Warholic, U.M., Patrick, D., Pawlicki, J.M., Beannan, R.O., Burce, A.H. and Paul, R.K. (2005) Escherichia coli virulence factor hemolysin induces neutrophil apoptosis and necrosis/lysis in vitro and lung injury in a rat pneumonia model. Am. J. Physiol. Lung Cell. Mol. Physiol., 289: 207-216.

19. Khan, A.W., Hossain, S.J. and Uddin, S.N. (2007) Isolation, identification and determination of antibiotics susceptibility of Vibrio parahaemolyticus from shrimps at Khulna region of Bangladesh. Res. J. Microbiol., 2: 216-227.

20. Faruque, S.M., Sack, D.A., Sack, R.B., Colwell, R.R., Takeda, Y. and Najir, G.B. (2008) Emergence and evaluation of Vibrio cholera O139. In: Proceedings of the National Academy of Sciences of the United States of America No. 100. p1304-1309.

21. Kaper, J.B., Morris, J.G. and Levine, M.M. (1995) Cholera. Clin. Microbiol. Rev., 8: 48-86.

22. Cheesbrough, M. (1985) Microbiology. In: Medical Laboratory Manual for Tropical Countries. $1^{\text {st }}$ ed. English Language Book Society, London. p400-480.

23. Buxton, A. and Fraser, G. (1977) Animal Microbiology. Blackwell Scientific Publications, Oxford, London, Edinburg, Melbourne. p400-480.

24. Cowan, S.T. (1985) Cowan and Steel's Manual for Identification of Bacteria. $2^{\text {nd }}$ ed. Cambridge University Press, Cambridge, London. p96-98.

25. Merchant, I.A. and Packer, R.A. (1967) The genus Salmonella. In: Veterinary Bacteriology and Virology. $7^{\text {th }}$ ed., Vol. 43. Iowa State University Press, Ames. Iowa, USA. p286-306.

26. Granum, P.E. (2001) Bacillus cereus. In: Doyle, M.P., Beuchat, L.R. and Montville, T.J., editors. International Food Microbiology: Fundamentals and Frontiers. $2^{\text {nd }}$ ed. ASM Press, Washington, DC. p373-381.

27. Chatterjee, C., Nag, N.C. and Ray, J.P. (1990) Studies on coagulase status and biochemical characters of animal strains of Staphylococci. Indian J. Anim. Health, 29: 157-161.

28. Zinnah, M.A., Haque, M.H., Islam, M.T., Hossain, M.T., Bari, M.R., Babu, S.A., Rahman, M.T. and Islam, M.A. (2008) Drug sensitivity pattern of E. coli isolated of samples of different biological and environmental sources. Bangladesh J. Vet. Med., 6: 13-18. 